Supplement of Geosci. Model Dev., 11, 165-194, 2018

https://doi.org/10.5194/gmd-11-165-2018-supplement

(C) Author(s) 2018. This work is distributed under

the Creative Commons Attribution 3.0 License.

(c) (1)



Supplement of

\title{
Development of an inorganic and organic aerosol model (CHIMERE $2017 \beta$ v1.0): seasonal and spatial evaluation over Europe
}

Florian Couvidat et al.

Correspondence to: Florian Couvidat (florian.couvidat@ ineris.fr)

The copyright of individual parts of the supplement might differ from the CC BY 3.0 License. 




Figure S1. Temporal evolution of modeled (red line) and measured (black line) $\mathrm{Na}^{+}$concentrations (in in $\mu \mathrm{g} \mathrm{m}^{-3}$ ) for station ES0008R. 
Table S1. Comparison of the Chimere 2013 version with the Chimere $2017 \beta$ version.

\begin{tabular}{|c|c|c|}
\hline & Chimere 2013 (Menut et al., 2013) & Chimere $2017 \beta$ \\
\hline Biogenic emissions & $\begin{array}{l}\text { older version of MEGAN (Guenther et al., 2006) } \\
\text { Monthly LAI at } 150 \text { arc seconds } \\
150 \text { arc seconds emission factors }\end{array}$ & $\begin{array}{l}\text { MEGAN } 2.1 \text { (Guenther et al., 2012) } \\
\text { 8-day LAI at } 30 \text { arc seconds } \\
30 \text { arc seconds emission factors }\end{array}$ \\
\hline Sea salt emissions & Monahan et al. (1986) & Monahan et al. (1986) \\
\hline Transport & Scheme of Van Leer (1979) & Scheme of Van Leer (1979) \\
\hline Gaseous chemistry & Melchior 2 (Derognat et al., 2003) & Melchior 2 (Derognat et al., 2003) \\
\hline $\begin{array}{l}\text { SOA thermodynamic } \\
\text { model }\end{array}$ & Tabulation of the AEC model (Bessagnet et al., 2008) & SOAP (Couvidat and Sartelet, 2015) \\
\hline $\begin{array}{l}\text { SIA thermodynamic } \\
\text { model }\end{array}$ & Tabulation of ISORROPIA (Nenes et al., 1998) & ISORROPIA 2.1 (Fountoukis and Nenes, 2007) \\
\hline $\begin{array}{l}\text { SIA formation mecha- } \\
\text { nism }\end{array}$ & $\begin{array}{l}\text { gas-phase oxidation of inorganic precursors from Mel- } \\
\text { chior } 2 \text { (Derognat et al., 2003) } \\
\text { aqueous-phase oxidation of } \mathrm{SO}_{2} \text { using a pH constrained } \\
\text { between } 4.5 \text { and } 6 \text { and computed by electroneutrality } \\
\text { with the concentrations of sulfate, nitrate and ammo- } \\
\text { nium }\end{array}$ & $\begin{array}{l}\text { gas-phase oxidation of inorganic precursors from Mel- } \\
\text { chior } 2 \text { (Derognat et al., 2003) } \\
\text { aqueous-phase oxidation of } \mathrm{SO} 2 \text { using an uncon- } \\
\text { strained pH computed by electroneutrality with the con- } \\
\text { centrations of sulfate, nitrate, ammonium, sodium, chlo- } \\
\text { ride and the concentrations of dissolved } \mathrm{SO}_{2}, \mathrm{CO}_{2} \text {, } \\
\mathrm{HNO}_{3}, \mathrm{NH}_{3}, \mathrm{HCl} \\
\mathrm{HNO}_{3} \text { condensing onto sea salts and dusts }\end{array}$ \\
\hline $\begin{array}{l}\text { SOA formation mecha- } \\
\text { nism }\end{array}$ & Bessagnet et al. (2008) & $\begin{array}{l}\mathrm{H}^{2} \mathrm{O} \text { with POA split into SVOC compounds (Couvidat } \\
\text { et al., 2012) }\end{array}$ \\
\hline Wet diameter & No estimation & Based on ISORROPIA and Semmler et al. (2006) \\
\hline Coagulation & $\begin{array}{l}\text { Gelbard and Seinfeld (1980) using parameters based on } \\
\text { Fuchs (1994) }\end{array}$ & $\begin{array}{l}\text { Jacobson and Turco (1994) based on the number of par- } \\
\text { ticles and using coagulation kernel coefficients of Debry } \\
\text { et al. (2007) }\end{array}$ \\
\hline Nucleation & Kulmala and Pirjola (1998) for sulfuric acid & Kulmala and Pirjola (1998) for sulfuric acid \\
\hline $\begin{array}{l}\text { Condensation Evapora- } \\
\text { tion }\end{array}$ & $\begin{array}{l}\text { Algorithm combining a dynamic approach with an equi- } \\
\text { librium approach based on Bowman et al. (1997) }\end{array}$ & $\begin{array}{l}\text { Pandis et al. (1993) using thermodynamic equilibria. } \\
\text { Condensing mass is redistributed over bins }\end{array}$ \\
\hline Wet deposition & $\begin{array}{l}\text { In cloud scavenging based on an empirical scavenging } \\
\text { coefficient } \\
\text { Below-cloud scavenging assuming a rain droplet diam- } \\
\text { eter of } 2 \text { mm taking into account the collision efficiency } \\
\text { between particles and raining drop and the irreversible } \\
\text { dissolution into rain droplets (Menut et al., 2013) }\end{array}$ & $\begin{array}{l}\text { In cloud scavenging proportional to the amount of cloud } \\
\text { water lost by precipitations (Croft et al., 2010) } \\
\text { Below-cloud scavenging using a polydisperse distribu- } \\
\text { tion of rain droplet diameters (Henzing et al., 2006) and } \\
\text { taking into account the collision efficiency between par- } \\
\text { ticles and raining drop and the irreversible dissolution } \\
\text { into rain droplets }\end{array}$ \\
\hline Dry deposition & Wesely (1989) & $\begin{array}{l}\text { Wesely (1989) using the wet diameter and density of } \\
\text { particles }\end{array}$ \\
\hline
\end{tabular}





Northern Europe

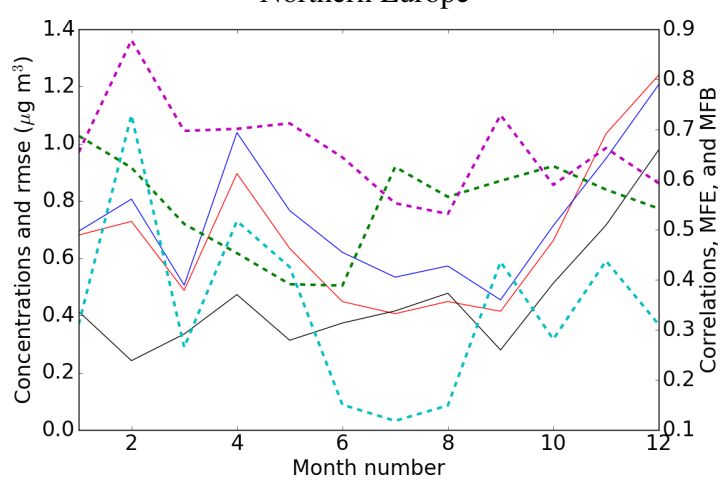



Eastern Europe

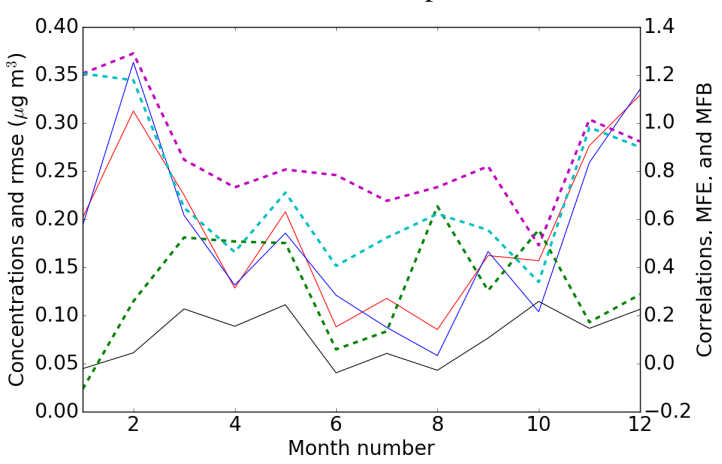

Southern Europe (without ES08)



Figure S2. Seasonal evolution of statistics by regions for $\mathrm{Na}^{+}$: Monthly mean measured concentrations (black), monthly mean modeled concentrations (red), monthly RMSE (blue), monthly spatiotemporal correlations (green), monthly MFB (cyan) and monthly MFE (magenta). Solid curves refer to the left axis while dotted curves refer to the right axis. 



Central Europe
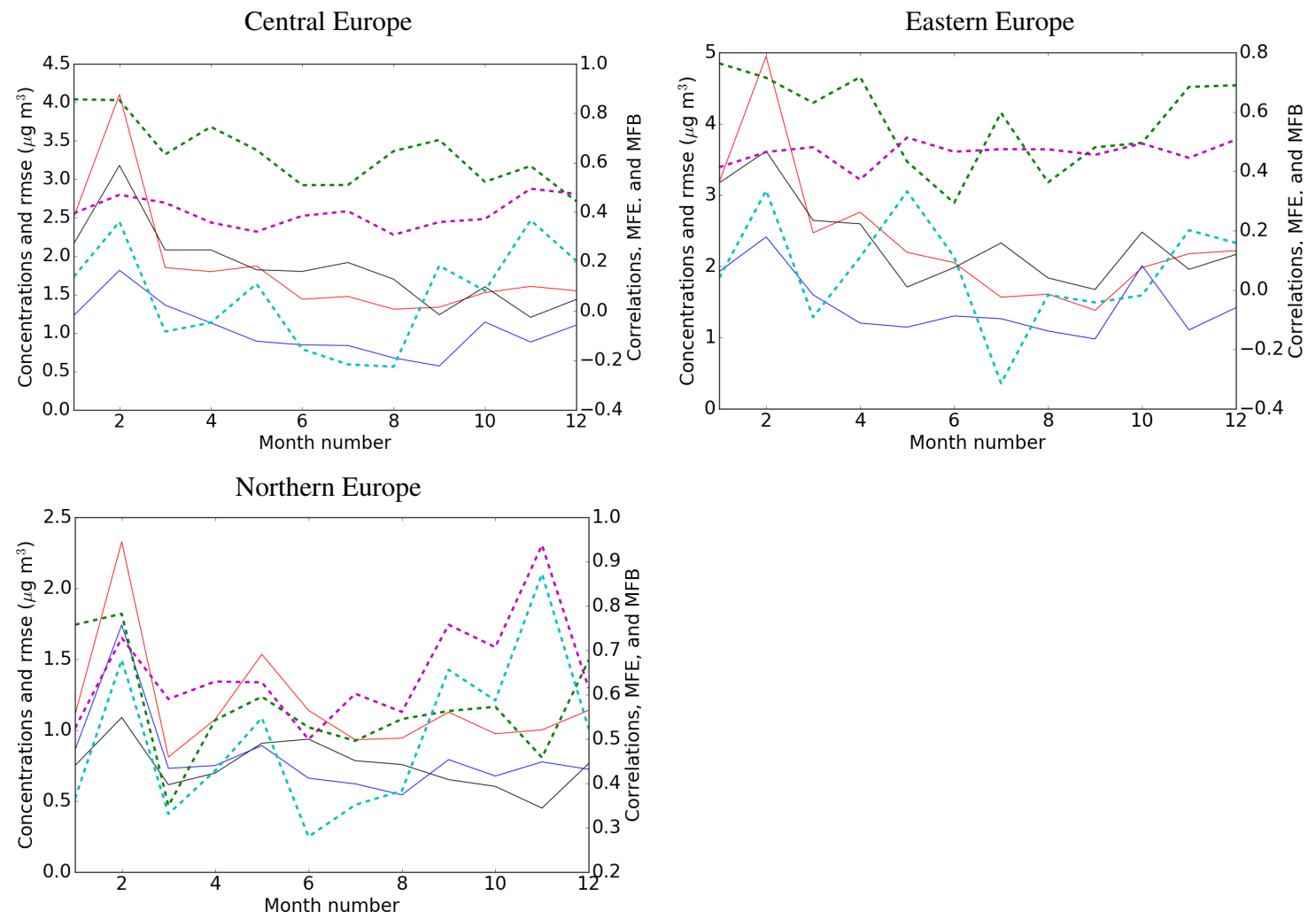

Figure S3. Seasonal evolution of statistics by regions for $\mathrm{SO}_{4}^{2-}$ : Monthly mean measured concentrations (black), monthly mean modeled concentrations (red), monthly RMSE (blue), monthly spatiotemporal correlations (green), monthly MFB (cyan) and monthly MFE (magenta). Solid curves refer to the left axis while dotted curves refer to the right axis. 
Southern Europe

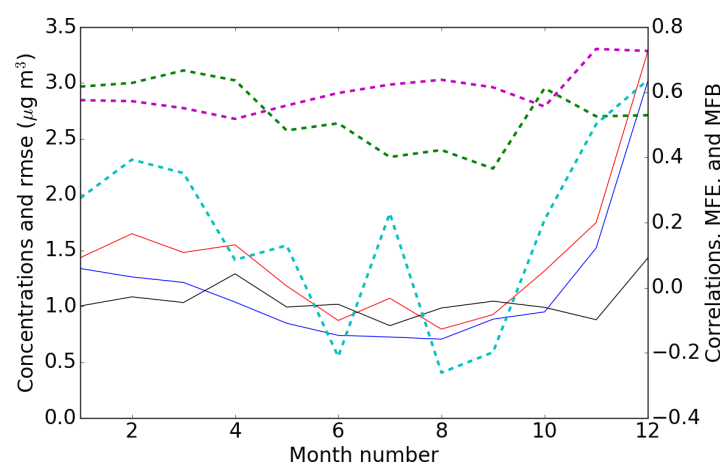

Central Europe

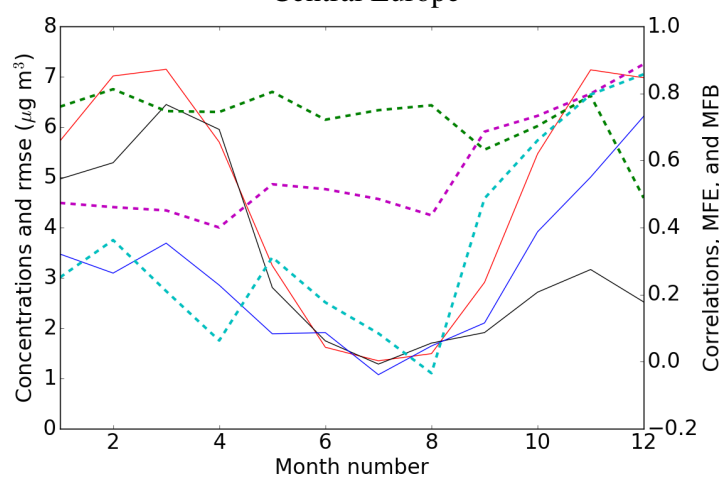

Northern Europe

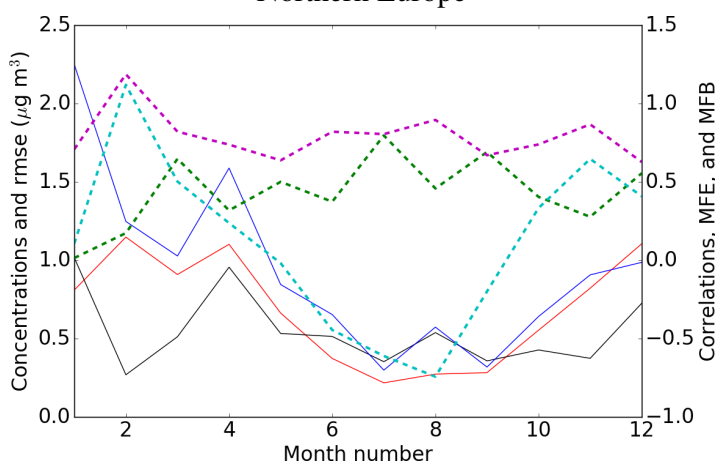

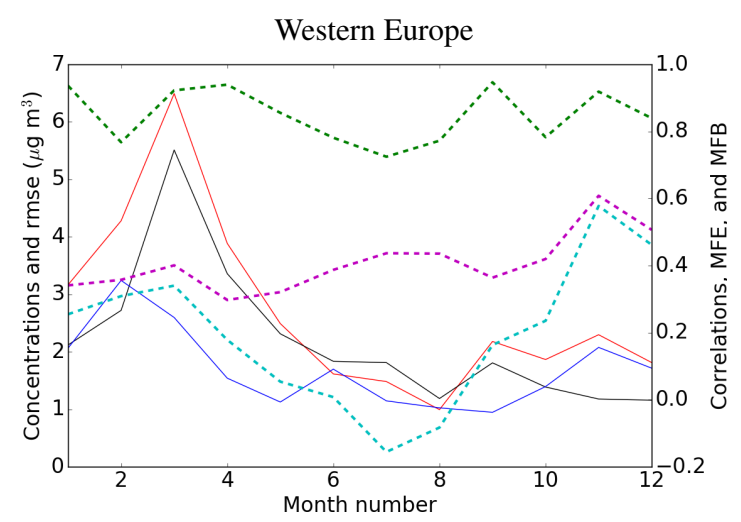

Eastern Europe

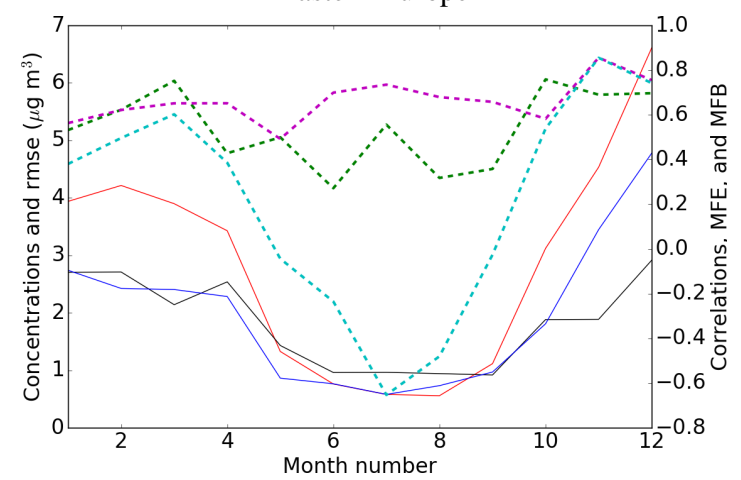

Figure S4. Seasonal evolution of statistics by regions for $\mathrm{NO}_{3}^{-}$: Monthly mean measured concentrations (black), monthly mean modeled concentrations (red), monthly RMSE (blue), monthly spatiotemporal correlations (green), monthly MFB (cyan) and monthly MFE (magenta). Solid curves refer to the left axis while dotted curves refer to the right axis. 





Eastern Europe



Figure S5. Seasonal evolution of statistics by regions for $\mathrm{NH}_{4}^{+}$: Monthly mean measured concentrations (black), monthly mean modeled concentrations (red), monthly RMSE (blue), monthly spatiotemporal correlations (green), monthly MFB (cyan) and monthly MFE (magenta). Solid curves refer to the left axis while dotted curves refer to the right axis. 

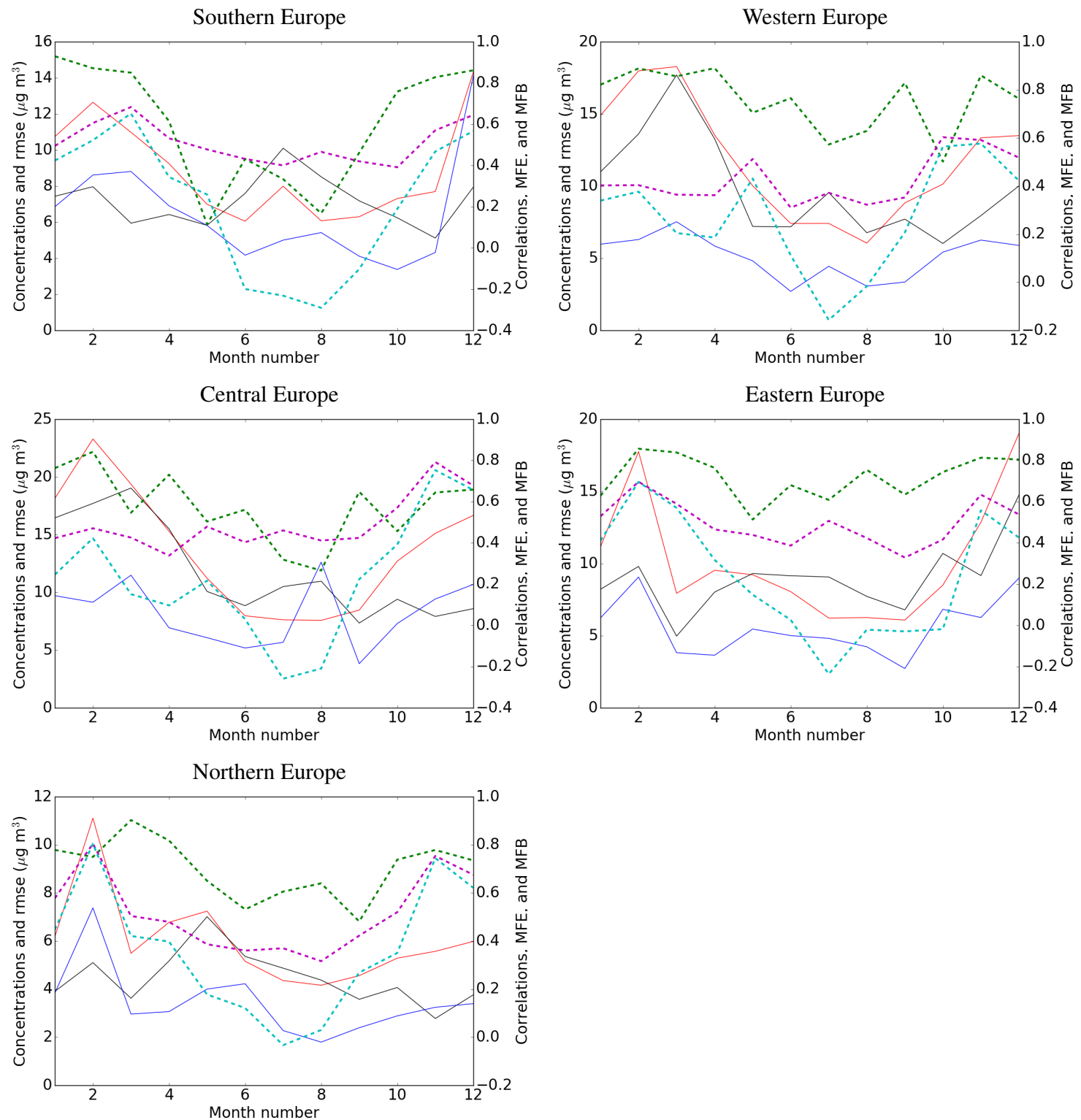

Figure S6. Seasonal evolution of statistics by regions for $\mathrm{PM}_{2.5}$ : Monthly mean measured concentrations (black), monthly mean modeled concentrations (red), monthly RMSE (blue), monthly spatiotemporal correlations (green), monthly MFB (cyan) and monthly MFE (magenta). Solid curves refer to the left axis while dotted curves refer to the right axis. 

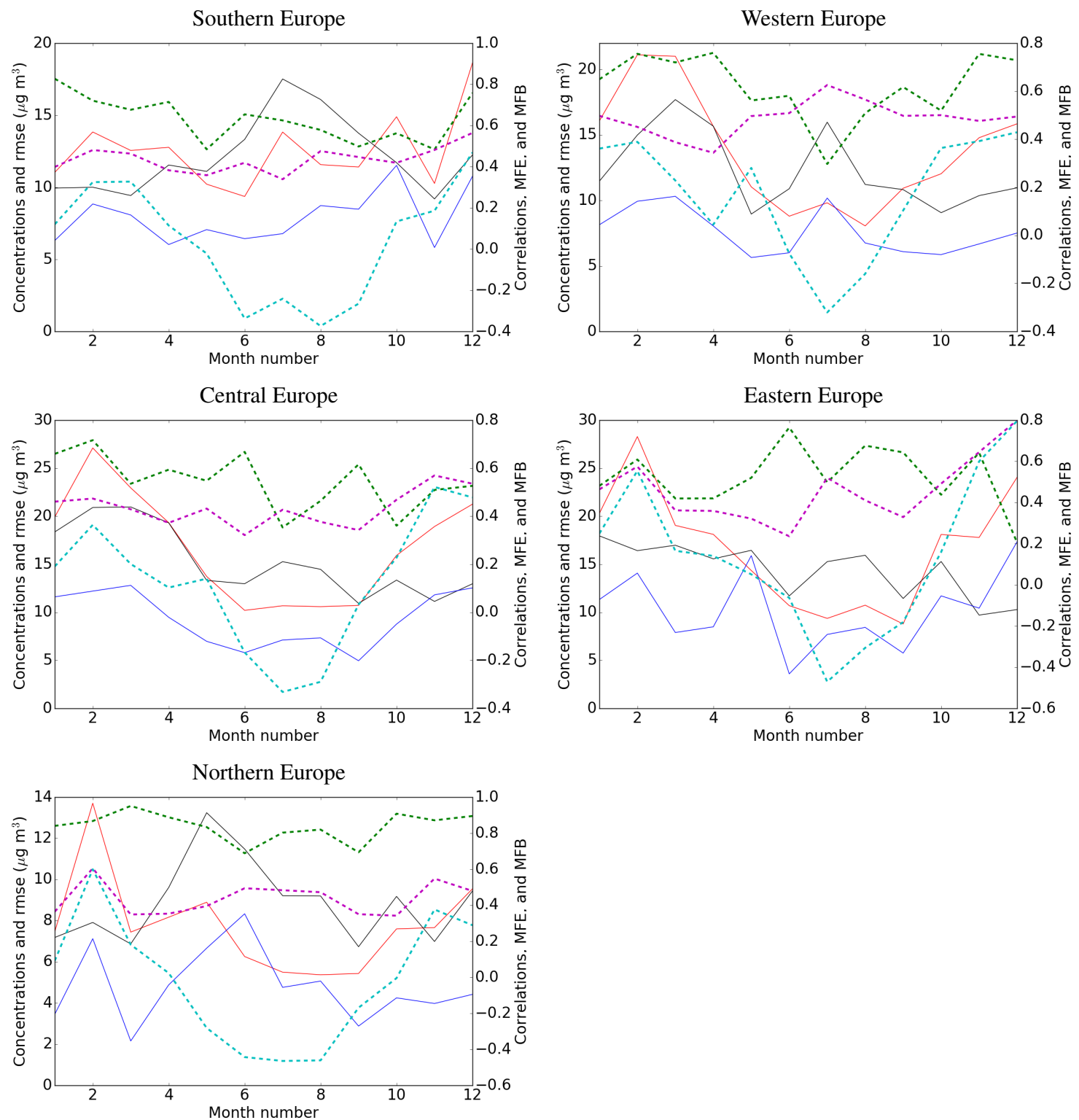

Figure S7. Seasonal evolution of statistics by regions for $\mathrm{PM}_{10}$ : Monthly mean measured concentrations (black), monthly mean modeled concentrations (red), monthly RMSE (blue), monthly spatiotemporal correlations (green), monthly MFB (cyan) and monthly MFE (magenta). Solid curves refer to the left axis while dotted curves refer to the right axis. 


\section{References}

Bessagnet, B., Menut, L., Curci, G., Hodzic, A., Guillaume, B., Liousse, C., Moukhtar, S., Pun, B., Seigneur, C., and Schulz, M.: Regional modeling of carbonaceous aerosols over Europe-focus on secondary organic aerosols, J. Atmos. Chem., 61, 175-202, doi:10.1007/s10874009-9129-2, 2008.

Bowman, F. m., Odum, J. R., Seinfeld, J. H., and Pandis, S. N.: Mathematical model for gas-particle parttioning of secondary organic aerosols, Atmos. Environ., 31, 3921-3931, doi:10.1016/S1352-2310(97)00245-8, 1997.

Couvidat, F. and Sartelet, K.: The Secondary Organic Aerosol Processor (SOAP v1.0) model: a unified model with different ranges of complexity based on the molecular surrogate approach, Geosci. Model Dev., 8, 1111-1138, doi:10.5194/gmd-8-1111-2015, 2015.

Couvidat, F., Debry, É., Sartelet, K., and Seigneur, C.: A Hydrophilic/Hydrophobic Organic $\left(\mathrm{H}^{2} \mathrm{O}\right)$ model: Model development, evaluation and sensitivity analysis, J. Geophys. Res., 117, D10 304, doi:10.1029/2011JD017214, 2012.

Croft, B., Lohmann, U., Martin, R. V., Stier, P., Wurzler, S., Feichter, J., Hoose, C., Heikkilä, U., van Donkelaar, A., and Ferrachat, S.: Influences of in-cloud aerosol scavenging parameterizations on aerosol concentrations and wet deposition in ECHAM5-HAM, Atmos. Chem. Phys., 10, 1511-1543, doi:10.5194/acp-10-1511-2010, 2010.

Debry, E., Fahey, K., Sartelet, K., Sportisse, B., and Tombette, M.: Technical Note: A new SIze REsolved Aerosol Model (SIREAM), Atmos. Chem. Phys., 7, 1537-1547, doi:10.5194/acp-7-1537-2007, 2007.

Derognat, C., Beekmann, M., Baeumle, M., Martin, D., and Schmidt, H.: Effect of biogenic volatile organic compound emissions on tropospheric chemistry during the Atmospheric Pollution Over the Paris Area (ESQUIF) campaign in the Ile-de-France region, J. Geophys. Res., 108, 8560, doi:10.1029/2001JD001421, 2003.

Fountoukis, C. and Nenes, A.: ISORROPIA II: a computationally efficient thermodynamic equilibrium model for $\mathrm{K}^{+}-\mathrm{Ca}^{2+}-\mathrm{Mg}^{2+}$ $-\mathrm{NH}_{4}^{+}-\mathrm{Na}^{+}-\mathrm{SO}_{4}^{2-}-\mathrm{NO}_{3}^{-}-\mathrm{Cl}^{-}-\mathrm{H}_{2} \mathrm{O}$ aerosols, Atmos. Chem. Phys., 7, 4639-4659, doi:10.5194/acp-7-4639-2007, 2007.

Fuchs, N.: The Mechanics of Aerosols, Pergamon Press, Oxford, 1994.

Gelbard, F. and Seinfeld, J. H.: Simulation of multicomponent aerosol dynamics, J. Colloid Int. Sci., 78, 485-501, doi:10.1016/00219797(80)90587-1, 1980.

Guenther, A., Karl, T., Harley, P., Wiedinmyer, C., Palmer, P. I., and Geron, C.: Estimates of global terrestrial isoprene emissions using MEGAN (Model of Emissions of Gases and Aerosols from Nature), Atmos. Chem. Phys., 6, 3181-3210, doi:10.5194/acp-6-3181-2006, 2006.

Guenther, A. B., Jiang, X., Heald, C. L., Sakulyanontvittaya, T., Duhl, T., Emmons, L. K., and Wang, X.: The Model of Emissions of Gases and Aerosols from Nature version 2.1 (MEGAN2.1): an extended and updated framework for modeling biogenic emissions, Geosci. Model Dev., 5, 1471-1492, doi:10.5194/gmd-5-1471-2012, 2012.

Henzing, J. S., Olivié, D. J. L., and van Velthoven, P. F. J.: A parameterization of size resolved below cloud scavenging of aerosols by rain, Atmos. Chem. Phys., 6, 3363-3375, doi:10.5194/acp-6-3363-2006, 2006.

Jacobson, M. Z. and Turco, R. P.: Modeling coagulation among particles of different composition and size, Atmos. Environ., 28, 1327-1338, doi:10.1016/1352-2310(94)90280-1, 1994.

Kulmala, M. A. L. and Pirjola, L.: Parameterization for sulfuric acid / water nucleation rates, J. Geophys. Res., 103, 8301-8307, doi:10.1029/97JD03718, 1998. 
Menut, L., Bessagnet, B., Khvorostyanov, D., Beekmann, M., Blond, N., Colette, A., Coll, I., Curci, G., Foret, G., Hodzic, A., Mailler, S., Meleux, F., Monge, J.-L., Pison, I., Siour, G., Turquety, S., Valari, M., Vautard, R., and Vivanco, M. G.: CHIMERE 2013: a model for regional atmospheric composition modelling, Geosci. Model Dev., 6, 981-1028, doi:10.5194/gmd-6-981-2013, 2013.

Monahan, E., Spiel, D., and Davidson, K.: Oceanic whitecaps and their role in air-sea exchange processes, chap. A model of marine aerosol generation via whitecaps and wave disruption, Dordrecht: D. Reidel Pub., 1986.

Nenes, A., Pandis, S. N., and Pilinis, C.: ISORROPIA: A new thermodynamic equilibrium model for multiphase multicomponent inorganic aerosols, Aquat. Geoch., 4, 123-152, 1998.

Pandis, S., Wexler, A., and Seinfeld, J.: Secondary organic aerosol formation and transport -II. Predicting the ambient secondary organic aerosol size distribution, Atmos. Environ., 27A, 2403-2416, doi:10.1016/0960-1686(93)90408-Q, 1993.

Semmler, M., Luo, B. P., and Koop, T.: Densities of liquid $\mathrm{H}^{+} / \mathrm{NH}_{4}^{+} / \mathrm{SO}_{4}^{2-} / \mathrm{NO}_{3}^{-} / \mathrm{H}_{2} \mathrm{O}$ solutions at tropospheric temperatures, Atmos. Environ., 40, 467-483, doi:10.1016/j.atmosenv.2005.09.056, 2006.

Van Leer, B.: Towards the ultimate conservative difference scheme, A second order sequel to Godunov's method, J. Computational Phys., 32, 101-136, doi:10.1016/0021-9991(79)90145-1, 1979.

Wesely, M.: Parameterization of Surface Resistances to Gaseous Dry Deposition in Regional-Scale Numerical Models, Atmos. Environ., 23, 1293-1304, doi:10.1016/0004-6981(89)90153-4, 1989. 